(C) К.A. Зверев

\title{
КОЛЛЕКТИВНАЯ ИДЕНТИЧНОСТЬ И ОБЩЕСТВЕННО-ПОЛИТИЧЕСКОЕ ПОВЕДЕНИЕ НАСЕЛЕНИЯ ЛИТВЫ ВО ВЗАИМОСВЯЗИ С ИСТОРИЧЕСКОЙ ГОСУДАРСТВЕННОЙ ПОЛИТИКОЙ
}

\begin{abstract}
В статье рассматривается процесс складывания коллективной идентичности населения независимой Литвы в период 1990-2010-х г2. во взаимосвязи с местной политикой памяти. В момент обретения самостоятельности, в 1991 г., Литва являлась полиэтничным государством, где наряду с литовцами, составлявшими до 79\% населения, проживали русскоязычные и поляки. В результате, местные власти столкнулись с необходимостью конструирования не только собственного политического механизма, вертикали власти, но и коллективной национальной идентичности, способной стать скрепляющим звеном нарождающейся государственности. Значительную роль в достижении данной цели сыграла литовская историческая политика, направленная не только на представителей титульного населения, но и на местные национальные меньшинства. В данной статье мы делаем попытку проследить особенности складывания коллективной идентичности, общественно-политического поведения литовцев, русскоязычных и поляков через исторические воззрения данных групп, а также степень восприимчивости населения Республики к государственной исторической парадигме.
\end{abstract}

Ключевые слова: государственное историческая политика, политика памяти, Литва, русскоязычное население

Ссылка при цитировании: Зверев $K . A$. Коллективная идентичность и общественно-политическое поведение населения Литвы во взаимосвязи с исторической государственной политикой // Вестник антропологии, 2021. № 3. С. 42-52.

В условиях «парада суверенитетов» и обретения независимости от СССР в 1991 г., целый ряд новых независимых государств - бывших советских республик, столкнулся с необходимостью конструирования не только собственного политического механизма, вертикали власти, но и коллективной национальной идентичности, способной стать скрепляющим звеном нарождающейся государственности. Особый интерес в данном вопросе, по нашему мнению, представляет Литовская Республика, которая не только одной из первых объявила о выходе из состава Советского Союза, но и ещё в 1992 г. создала прообраз института национальной памяти, призванный данную коллективную идентичность формировать посредством истории. Кроме того, дополнительную актуальность исследованию придаёт относительно слабая изученность новейшего периода истории Литвы в отечественной историографии.

Зверев Кирилл Александрович - к.и.н., доцент кафедры истории Института гуманитарных наук и социальных технологий, Костромской государственный университет (156005 г. Кострома, ул. Дзержинского, 17). Эл. адрес: zwerew.kir@yandex.ru 
Государственная историческая политика любой страны всегда в первую очередь нацелена на внутреннего потребителя - на местное население. Литва в данном отношении не является исключением, однако здесь формирование коллективной идентичности затрудняет многоэтничный характер республики, где на момент провозглашения независимости, литовцы составляли 79\% населения, русскоязычные - $12 \%$, поляки - 7\% (Lietuvos statistikos metraštis 1989). В данной статье мы делаем попытку проследить становление коллективной идентичности, общественно-политическое поведение литовцев, русскоязычных и поляков через исторические воззрения данных групп, а также степень восприимчивости населения Республики к государственной исторической парадигме.

Начать хотелось бы с периода «поющей революции», когда в Литве был проведён опрос о независимости - 9 февраля 1991 г. В результате, за отделение от СССР проголосовали 90,5\% избирателей (2 028 339) при явке 84,7\% (Ar just uz tai kai Lietuvos valstybe būtų nepriklabsoma demokratine Respublika? 1991). При этом, в Вильнюсе за независимость высказались 80,6\%, в Клайпеде 89,3\%, в Игналинском районе (в том числе городе Висагинасе) 83.6\% (Там же 1991). Если сопоставить соотношение литовского и русскоязычного населения по данным населённым пунктам, согласно переписи 1989 г. (Lietuvos statistikos metraštis 1989), то получается, что доля литовцев в населении Вильнюса составляет 50\% (с поляками 70\%), в Клайпеде - 61,5\%, в Игналинском районе - 30\% вместе с поляками. Поэтому мы можем предположить, что за независимость Литвы высказалось от 30 до 50\% местных русскоязычных - это гораздо больше, чем в соседних Эстонии и Латвии. При этом наибольший скептицизм по поводу самостоятельного Литовского государства проявили местные поляки - в месте их компактного проживания - Шальчининкском районе (лит. Šalčininkų rajono savivaldybe) с 80\% польским населением - за независимость высказалось лишь 52,8\% - минимальный показатель опроса 9 февраля 1991 г. (Там же 1991).

Столь высокую поддержку идеи независимости жителями можно объяснить следующими обстоятельствами. Ещё на рубеже 1980-1990-х гг. в Литве шёл процесс наибольшей в Прибалтийском регионе радикализации общества. Этому способствовал более однородный этнический состав населения Республики (по сравнению с северными соседями), опыт длительного сопротивления советской власти в послевоенный период, сильные позиции римско-католической церкви, а также традиционно оппозиционные настроения местной интеллигенции. Другими словами, литовское общество в тот момент имело высокую степень этнорелигиозной однородности и могло не опасаться угрозы раскола по политическим мотивам, в отличие от Эстонии и Латвии, где проживало значительное русскоязычное население (в том числе в приграничных с Россией территориях). Кровавый исход событий у Вильнюского телецентра, без сомнения, ещё более консолидировал литовское общество. Поэтому не удивительно, что именно здесь с первых лет независимости начала оформляться вполне внятная государственная историческая парадигма, позднее воплощённая в виде исторической политики. В частности, это выразилось в открытии в 1992 г. одного из первых в Восточной Европе Институтов национальной памяти, а именно «Центра исследования геноцида и резистенции жителей Литвы» и музея оккупации при нём. Интересно, что вопрос о названии данного центра и его задачах - «восстановление исторической правды и справедливости, изучение проводимого оккупационными режимами в 1939-1990 гг. физического и духовного геноцида населения 
Литвы и его сопротивления этим режимам, увековечение памяти борцов за свободу и жертв геноцида, инициирование правовой оценки последствий оккупации» (цит. по: Закон 1997) не вызвал каких-либо бурных дискуссий в Сейме Литовской Республики ни в 1992 г., ни в последующие годы, когда обсуждалась деятельность данного Института национальной памяти (Stenograma 1992). Уже сама постановка задач центра даёт нам представление о круге исторических вопросов, волновавших как политический истеблишмент, так и само литовское общество (в первую очередь - это события Второй Мировой войны и обстоятельства инкорпорации Литвы в состав СССР). Кроме того, как видим, «польский вопрос» и принадлежность Виленского края здесь явно отходят на второй план после литуанизации последнего. Центр внимания перемещается на рассмотрение периода «советской оккупации». Сама же историческая парадигма официального Вильнюса зиждется помимо концепции оккупации стран Балтии, ещё и на литуанизации истории Великого княжества Литовского, что оказывает прямое влияние на внутри- и внешнеполитическое развитие, а также позиционирование современной Литовской Республики (Зверев 2020: 03-13).

В целом, антисоветская / антироссийская риторика литовской политики памяти оказалась весьма восприимчива среди местного населения. Так, согласно социологическим исследованиям 2016 г. лишь 26\% респондентов согласились с утверждением, что в советское время жизнь в Литве была лучше, чем сейчас (Давидоните 2016). Интересна и подборка дружественных государств по отношению к Литве, согласно этому же опросу - наиболее дружественными литовцы считают Латвию (93\%), на втором месте - Германия (87\%), потом идет США - 85\%, Польша - 81\%, Беларусь - 55\%, хуже всего оценили Россию (14\%). Большинство (60\%) участников опроса придерживаются мнения, что внешняя политика России представляет угрозу для Литвы (Там же 2016). Т.е. русофобская составляющая государственной исторической политики в полной мере достигла своих целей.

Весьма спорным моментом в литовской политике памяти является активная отсылка к Великому княжеству Литовскому (ВКЛ) как колыбели национальной государственности и предтечи современной Литвы - литуанизация истории ВКЛ, в том числе «восстановление» Дворца Властителей Литвы (имеется в виду часть комплекса Нижнего замка в Вильнюсе, которая служила и как резиденция великих князей ВКЛ - королей Польши, во время их пребывания в Вильнюсе до середины XVII в.). Дворец представляется как символ долговечной литовской (в этническом смысле) государственности, который был разрушен во время захвата Вильно русскими войсками в 1655 и окончательно снесён после 3-го раздела Речи Посполитой и присоединения территории современной Литвы к Российской империи. На самом деле, по мнению литовских исследователей это здание никогда не носило такого исторического смысла, да и понятие самостоятельности («равноправия») ВКЛ в составе Речи Посполитой не имело «национального» в сегодняшнем понимании характера (Шепетис 2009: 163).

Ряд литовских историков и политологов - Альвидас Йокубайтис, Витаутас Раджвилас, Инги Винограднайте не считают целесообразным связывать современную Литовскую Республику с Великим княжеством Литовским, так как последнее являлось многонациональной, польскоязычной аристократической монархией, имевшей мало общего с современным национальным государством. Целесообразней, по мнению учёных, прослеживать правопреемство Литовской Республики с национального 
пробуждения XIX в. и оформления Первого литовского государства в 1918 г. ( $\mathrm{Ca}$ мошкайте 2012) Солидарны с исследователями и местные жители. Так, по заказу литовского информационного портала DELFI компанией по исследованию общественного мнения и рынка Spinter tyrimai было проведено социологическое исследование в январе 2012 г., согласно которому с государственностью у жителей Литвы наиболее всего ассоциируется праздничный день 16 февраля (1918 г.) - провозглашение независимости первой Литовской Республики (поддержали 45,6\% респондентов), в то время как День коронации короля Миндаугаса и знаменующееся этим создание Великого княжества Литовского (22,2\% опрошенных), 11 марта (20,3\%) или нынешний День Конституции $(1,6 \%)$ в сознании жителей Литвы утвердились гораздо слабее (DELFI.lv 2012) (см. табл. 1).

Таблица 1

\section{Отношение жителей Литвы к основным памятным датам ((DELFI.lv 2012)}

\begin{tabular}{|c|c|}
\hline $\begin{array}{l}\text { Какой день для вас в наибольшей степени ассоциируется с государ- } \\
\text { ственностью? }\end{array}$ & \\
\hline $\begin{array}{l}16 \text { февраля } 1918 \text { - День восстановления литовского государства (провоз- } \\
\text { глашение независимости Литвы) }\end{array}$ & $45,6 \%$ \\
\hline $\begin{array}{l}6 \text { июля } 1253 \text { - День литовского государства (коронация короля Миндауга- } \\
\text { са [Миндовга], основание Великого княжества Литовского) }\end{array}$ & $22,2 \%$ \\
\hline $\begin{array}{l}11 \text { марта } 1990 \text { - День восстановления независимости Литвы } \\
\text { (принятие Акта о восстановления независимости Литвы) }\end{array}$ & $20,3 \%$ \\
\hline 25 октября 1992 - День Конституции (принятие конституции Литвы) & $1,6 \%$ \\
\hline Ни один из них & $6,3 \%$ \\
\hline Не знаю/не ответили & $3,6 \%$ \\
\hline Всего & $100 \%$ \\
\hline
\end{tabular}

Другими словами, по мнению члена Института истории Литвы Альгимантаса Каспаравичюса, большинство литовцев ассоциируют себя с межвоенной Литвой, но не Великим княжеством Литовским (Там же 2012). Аналогичного мнения придерживается и философ Арвидас Юозайтис, который считает, что «16 февраля (1918 г.) стал поворотным моментом, показав, что литовцы полны решимости отделить свою культуру от польской и создать собственное государство. В этот день были заложены основы для выживания нации и её культуры» (Juozaitis 2012).

Прозападная и одновременно антироссийская риторика исторического контекста нашла понимание в обществе в виде благосклонного отношения к евроатлантической интеграции официального Вильнюса. Так, вступление Литвы в Европейский Союз на референдуме 10-11 мая 2003 г. поддержали 91\% проголосовавших (Referendumas 2003). Вопрос о вступлении в НАТО на всеобщий плебисцит вынесен не был, однако социологические исследования 2002 г. показали, что 65\% населения поддержали бы интеграцию Литвы в НАТО при голосовании (DELFI.lv 2003). 
Таким образом, можно констатировать, что литовская политика памяти оказалась весьма успешной в части восприятия гражданами принципа континуитета (правопреемства нынешней Литовской Республики к государству межвоенного периода), умеренного законодательного реституционализма и антисоветской/антироссийской составляющей. Однако, апеллирование к Великому княжеству Литовскому и попытка провести параллели с современной Литовской Республикой как преемницей ВКЛ не нашли поддержки ни среди населения, ни среди научного сообщества.

Тем не менее, следует учесть, что государственная историческая политика стран Балтии, и Литвы, в частности, с момента своего оформления в 1990-х гг. была нацелена помимо титульного населения республик и на местные национальные меньшинства - русскоязычных (до 6,5\% жителей) и поляков (6,7\%) (Lietuvos gyventojai 2006: 170).

Часть русскоязычного населения, как мы упоминали выше, ещё в 1991 г. поддержало Литву на пути к независимости. Однако, если обратиться к 2010-м гг., то настроения местных национальных меньшинств возможно выяснить благодаря социологическим исследованиям - в частности, представляет интерес опрос компании по изучению общественного мнения Baltijos tyrimai (рус. Балтийские исследования), проведённый 27 июня - 12 июля 2016 г. Состав респондентов был исключительно из числа нелитовцев: 46\% - поляки, 35\% - русские, $8 \%$ - белорусы, $6 \%$ - украинцы, $2 \%$ - евреи и $3 \%$ - представители других национальностей. $64,8 \%$ участников исследования положительно ответили на вопрос, защищали бы они Литву, если бы на неё напали. В 2014 г. в Литве высказались утвердительно по аналогичному вопросу 57\% населения, в 2005 г. - 32\% (DELFI.lv 2016). Другими словами, степень лояльности к официальному Вильнюсу среди национальных меньшинств за 10 лет практически удвоилась. В том же 2016 г., с утверждением, что граждане Литвы стали бы защищать свою страну в случае агрессии больше соглашались русские - $65 \%$, в числе поляков таковых было меньше - 59,9\%. «В вопросе обороны страны русские всегда были активнее, особенно жители младшего возраста, которые отождествляют себя с этим государством», - отметил заместитель директора Baltijos tyrimai Ромас Мачюнас (цит. по: Там же 2016).

Однако, при этом, только 42,8\% участников опроса согласны с утверждением, что для безопасности Литвы важны членство в ЕС и НАТО. Между тем, утверждение, что часть представителей нацменьшинств нелояльны по отношению к Литве, были оценены следующим образом - меньше трети с этим согласились, 33,4\% не сказали ни да, ни нет, 31,2\% не согласились. Интересные результаты показали и вопросы о международной политике. К примеру, больше половины - 52,8\% - участников опроса согласны с утверждением, что российская политика - адекватная реакция на направленные против неё действия США и НАТО. Кроме того, присоединение Крыма к РФ законным действием считают 42,8\% участников опроса. Больше всего это утверждение поддерживали выпускники русскоязычных школ - 48,3\%, среди выпускников польских школ - 39,5\%. Наконец, 40,8\% участников опроса согласились с мнением, что «развал СССР - это самая большая геополитическая катастрофа». Интересно, что с этим были склонны согласиться воспитанники польских школ $(43,4 \%)$, учащихся русских школ с таким мнением было немного меньше (41,2\%) (DELFI.lv 2016).

Представленные выше данные свидетельствуют с одной стороны-о высокой степени лояльности представителей национальных меньшинств к Литовскому государству 
(в особенности молодого поколения, которое выросло уже в независимой Республике), с другой стороны - до половины местного русскоязычного и польского населения не восприняли значительное количество тезисов литовской политики памяти, в частности её антисоветскую и антироссийскую составляющие. Это может быть следствием существования в Литовской Республике, как и в соседних Эстонии и Латвии, двух информационных полей - литовскоязычного (для представителей титульного населения) и русскоязычного. Подтверждают наше суждение результаты другого социологического опроса, согласно которому в 2016 г. 90\% представителей национальных меньшинств в качестве источника информации использовали российские СМИ (Tautinès bendrijos 2016). Официальный Вильнюс, недовольный доминированием иностранного информационного поля среди нелитовцев, с 2013 г. начал вводить ограничения на вещание «Первого Балтийского канала» (ПБК), «РТР-Планета», «Russia Today» (RT), местный филиал российского агентства «Спутник» и др. (Разумовский 2020).

Кроме того, опросы показывают довольно схожие оценки у польского и русскоязычного меньшинств, представители которых оказались в похожих условиях с одинаковыми задачами по сохранению собственной идентичности, образования на родном языке и политического представительства в независимой Литве. При этом сами литовцы более благосклонно относятся именно к местным русским - об этом свидетельствуют данные социологического исследования 2011 г. Так, русское национальное меньшинство положительно оценивают три из четырех жителей страны $(77 \%)$. Отрицательное мнение по поводу русских разделяют $20 \%$ респондентов. О поляках положительное мнение сложилось у $57 \%$ опрошенных, а отрицательное - у $38 \%$, свидетельствует исследование американской неправительственной организации Pew Research Center (Опрос 2011). Данные цифры могут говорить, помимо прочего, и о восприятии в массовом сознании литовского большинства местных поляков как потенциальных «сепаратистов», угрожающих единству Литовского государства и Виленского края, как его части.

Представляют для нас интерес и результаты социологического исследования «Историческое осознание важнейших событий прошлого века в Восточной Европе», которое показало отношение жителей Литвы (и титульного населения, и представителей национальных меньшинств) к основным событиям и личностям XX в. (Ajalooteadvus eelmise sajandi olulisematest sündmustest 2009) Согласно полученным результатам, $51 \%$ жителей заявили, что интересуются историей своей страны, а 46\% испытывают интерес к событиям ХХ в. (Там же 2009). Особенную ценность здесь представляют оценочные суждения молодёжи младше 30 лет, взгляды которой более критичны к советскому периоду, нежели у возрастных респондентов. И наоборот, литовская молодёжь гораздо положительнее отзывается о независимом Литовском государстве и его деятелях (см. рис. 1). Так, Антанас Сметона (первый президент независимой Литвы, с 1926 до инкорпорации Литвы с состав СССР в 1940 - лидер авторитарного режима в Республике), как и Юстинас Марцинкявичюс (литовский поэт и драматург, годы жизни 1930-2011) молодёжью были оценены в среднем на 10\% более положительно, нежели другими возрастными группами. При этом, Антанас Снечкус (первый секретарь Литовской ССР в 1940-1974 гг.) и Альгирдас Бразаускас (первый секретарь Литовской ССР в 1988-1987 гг., президент Литвы в 1993-1998 и премьер-министр в 2001-2006 гг.) оказались менее популярны в молодёжной среде. 


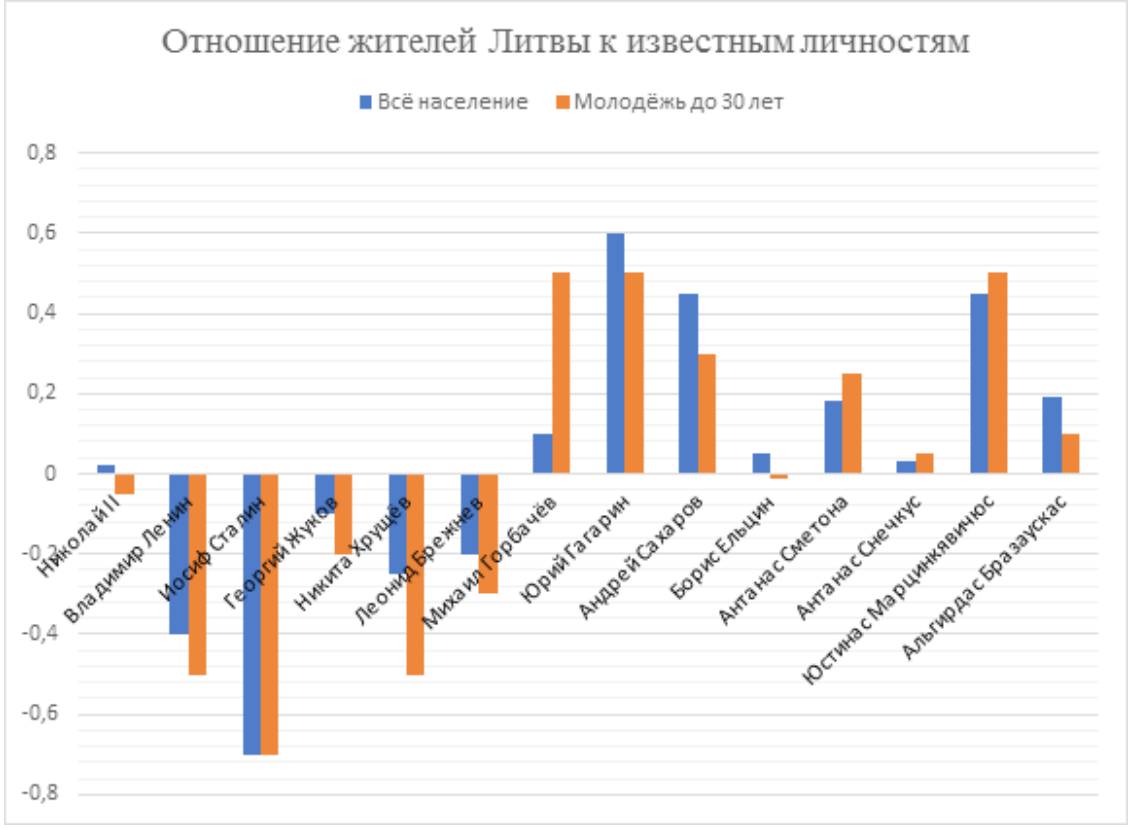

Рис. 1. Отношение жителей Литвы к известным личностям ХХ в. (Исследовательский проект 2009: 35)

Можно констатировать, что литовской политике памяти удалось привить местному обществу и молодёжи в том числе идеалистический образ Литовской Республики межвоенного периода и негативное отношение к советскому прошлому. Однако, респонденты моложе 30 лет критичнее воспринимают и современное Литовское государство, давая сдержанные оценки одному из наиболее известных политических деятелей новейшей истории Литвы - Альгирдасу Бразаускасу.

Если же обратиться к литовской историографии, то она развивается, за редким исключением, в русле местной государственной исторической парадигмы (литуанизация истории Великого княжества Литовского, идеализация Республики 1918-1940 гг., трактовка периода существования Литовской ССР как периода «советской оккупации», оценка деятельности лесных братьев как движения патриотов Литвы, борцов за независимость против «советской оккупации») (Zinkevičius Z.: 1993; Eidintas 2013: 7074; Kiaupa 2002: 109-123). Исключением являются разве что работы литовских исследователей Витаутаса Петкявичюса (Петкявичюс 2004), Юозаса Куолялиса (Kuolelis 2010), Валерия Иванова (Иванов 2018), подвергающие сомнению основные постулаты исторической политики официального Вильнюса и подвергавшиеся преследованию за свои взгляды (Сапожникова 2016). Наиболее критично настроенные исследования по интересующей нас тематике изданы в РФ (Гарапко 2016: 69-74; Дюков 2013; Воробьева 2010; Демурина, Симиндей 2009). В целом, в Литве не сформировалось научно-популярной альтернативы государственной исторической парадигмы, в том числе, и по причине незаинтересованности в этом местного истеблишмента, а также недопредставленности представителей нетитульного населения в научной сфере.

Подводя итог, необходимо отметить, что взгляды русскоязычного и польского населения Литвы на местную историю весьма схожи - нейтральное восприятие периода Великого княжества Литовского, позитивная оценка первой буржуазной Ре- 
спублики 1920-х - 1930-х гг. и её политических лидеров, но критичное отношение к тезису о «советской оккупации». Хотя оценочные суждения молодого поколения (младше 30 лет) и отличаются от мнения более возрастных респондентов в сторону менее лояльного отношения к советскому прошлому, тем не менее, и здесь не произошло перехода к доминированию антисоветских взглядов и поддержки тезисов об «оккупации». Таким образом, ключевые аспекты местной государственной исторической политики оказали существенное влияние на коллективную идентичность и общественно-политическое поведение жителей Литвы, в первую очередь - на представителей титульного населения. Среди литовских русскоязычных и поляков, всё-таки доминирует более лояльное отношение к советскому прошлому и Российской Федерации, использование русскоязычного информационного поля в качестве источника информации. Однако, социологические исследования показывают тенденцию к сближению точек зрения местных национальных меньшинств с историческими воззрениями титульного населения. Вследствие активизации политики памяти в 2000-е - 2010-е гг. мы можем предположить, что в ближайшие десятилетия основные постулаты, продвигаемые государственной исторической политикой Литвы, станут доминирующими среди местного русскоязычного и польского населения.

\section{Источники и материалы}

Ajalooteadvus eelmise sajandi olulisematest sündmustest Ida-Euroopa aladel. Aprill-mai 2009.a. Saar Poll, september 2009.a // SAAR POLL (Саар Полл). http://www.saarpoll.ee/UserFiles/ File/Ajalooteadvuse_uuringu_esitlus_23_09_2009.pdf (дата обращения 08.11.2020).

Закон о Центре по изучению геноцида и резистенции населения Литвы // Vedomosti Litovskoi Respubliki, 1997-09-10, Nr. 25-288. https://e-seimas.lrs.lt/portal/legalAct/lt/TAD/TAIS.43653 (дата обращения: 11.08.2020).

Иванов B.B. Гекатомба. Трилогия. Часть 2. Страшная ночь. К вопросу о жертвах ночи 13 января 1991 г. в Вильнюсе. Сборник документов. Вильнюс, 2006. https://www.proza. $\mathrm{ru} / 2010 / 01 / 06 / 1087$ (дата обращения 08.12.2019).

Разумовский $A$. Наполовину пуст: страны Балтии убирают из эфира российские телеканалы // Известия. 2020. 16 июля. https://iz.ru/1035064/andrei-razumovskii/napolovinu-puststrany-baltii-ubiraiut-iz-efira-rossiiskie-telekanaly (дата обращения 29.11.2020).

Juozaitis A.: Vasario 16-oji buvo esminio lūžio taškas Lietuvos istorijoje (А. Юозайтис: 16 февраля стало поворотным моментом в истории Литвы) // Lietuvos rytas. https://kultura.lrytas. 1t/-13288031681327725490-a-juozaitis-vasario-16-oji-buvo-esminio-1\%C5\%AB\%C5\%BEiota\%C5\%A1kas-lietuvos-istorijoje.htm (дата обращения 24.10.2020).

Lietuvos gyventojai: struktūra ir demografinè raida (Population of Lithuania: Composition and Demographic De-velopment)/ Redaktoriai: D. Ambrozaitienè. Vilnius: Statistikos departamentas prie Lietuvos Respublikos Vyriausybès, 2006. 178 p.

Lietuvos statistikos metraštis 1989 // Official Statistics portal http://osp.stat.gov.lt/statistikosleidiniu-katalogas?publication=83 (дата обращения 23.09.2020).

Referendumas dèl Lietuvos Respublikos narystès Europos Sajungoje // Lietuvos Respublikos Vyriausioji rinkimų komisija (Центральная избирательная комиссия Литовской Республики). https://web.archive.org/web/20110324201242/http://www3.lrs.lt/rinkimai/2003/referendumas/ (дата обращения 25.10.2020).

Seimo vakarinis neeilinis posedis Nr. -2 Stenograma (1992-10-29) (Стенограмма № 2 вечернего заседания Сейма от 29.10.1992) // Сайт Сейма Литовской Республики. https://e-seimas. lrs.lt/portal/legalAct/lt/TAK/TAIS.251744 (дата обращения: 20.10.2020); Seimo rytinis posédis Nr. 77 Stenograma (1997-06-05) (Стенограмма № 77 утреннего заседания Сейма от 05.06.1997) // Сайт Сейма Литовской Республики. https://e-seimas.lrs.lt/portal/legalAct/lt/ 
TAK/TAIS.49352 (дата обращения: 21.10.2020).

Tautinès bendrijos, žiniasklaidos priemonès ir pasitikëjimas. Tyrimo ataskaita. Klaipėda: Klaipėdos universiteto Socialinių pokyčių studijų centras, 2016. L. 23.

Для жителей Литвы смысл государственности несет 16 февраля, а не 11 марта // rus.DELFI. lv. https://ru.delfi.lt/news/live/dlya-zhitelej-litvy-smysl-gosudarstvennosti-neset-16-fevralya-ane-11-marta.d?id=55573301 (дата обращения 24.10.2020).

Исследование: что делали бы русские и поляки Литвы, если бы на страны Балтии напала Россия? // rus.DELFI.lv 2016. 8 августа. https://ru.delfi.lt/news/live/issledovanie-chto-delaliby-russkie-i-polyaki-litvy-esli-by-na-strany-baltii-napala-rossiya.d?id=71992604 (дата обращения 27.11.2020).

Исследовательский проект «Восприятие молодёжью новых независимых государств истории советского и постсоветского периодов». Апрель-май 2009 г. Краткий аналитический отчёт. М.: НП «Евразийский монитор», АНО «Социологическая мастерская Задорина», 2009. С. 35.

Опрос: Литовцы на русское нацменьшинство смотрят более благосклонно, чем на местных поляков // Литовский курьеръ. 2011. 21 декабря. https://www.kurier.lt/opros-litovtsy-narusskoe-natsmenshins/ (дата обращения 14.11.2020).

Ar just uz tai kai Lietuvos valstybe būtų nepriklabsoma demokratine Respublika? // Lietuvos aidas. 1991, Vasario 14 d. Referendumo rezultatai. Šaltinis: 1991 m. vasario 14 d. „Lietuvos aidas”, p. 4 //Lietuvos Respublikos vyriausioji rinkimų komisija https://www.vrk.lt/documents/10180/66 8587/1991+02+09+rezultatai.jpg/e3f70e07-6372-4ebf-a405-b381 aa1 da542?t=1537441306041 (дата обращения 22.09.2020).

Du iš 3 Lietuvos gyventojų balsuotų už narystę NATO // rus.DELFI.lv https://www.delfi.lt/news/ daily/lithuania/du-is-3-lietuvos-gyventoju-balsuotu-uz-naryste-nato.d?id=1734335 (дата обращения 25.10.2020).

\section{Научная литература}

Воробьева Л. (под ред.) История Латвии от Российской империи к СССР. Книга 2. М.: Фонд «Историческая память», 2010.

Гарапко В.Ф. Мировоззренческие парадигмы и идеологемы внешней политики современной Литвы // International scientific review, 2016. № 3 (13). С. 69-74.

Давидоните Б. Исследование: как в Литве оценивают жизнь в советские времена? // ru.DELFI. lt 2016. 25 августа. https://ru.delfi.lt/news/live/issledovanie-kak-v-litve-ocenivayut-zhizn-vsovetskie-vremena.d?id=72137384 (дата обращения: 20.10.2020).

Демурин М. В., Симиндей B.B. (под ред.) Современная европейская этнократия: Нарушение прав национальных меньшинств в Эстонии и Латвии. М.: Фонд «Историческая память», 2009. 279 c.

Дюков А.P. Протекторат «Литва». Тайное сотрудничество с нацистами и нереализованный сценарий утраты литовской независимости, 1939-1940 гг. М.: Фонд «Историческая память, 2013. $264 \mathrm{c.}$

Зверев К.А. Формирование официальной исторической парадигмы независимой Литвы // Всеобщая история, 2020. № 3. С. 3-13.

Иванов B.B. De jure и de facto: история формирования этнополитического государства литовцев в межвоенный период 1919-1941 гг./ в 4-х томах. Вильнюс, 2018.

Петкявичюс В. Корабль дураков: Галерея политических портретов и шаржей; пер. с лит. В. Мещерякова, Н. Ковяковой. Калининград: Янтарный сказ, 2004. 310 с.

Самошкайте Э., Йокубайтис А: Литовская Республика не является продолжением Великого княжества Литовского // rus.DELFI.lv https://www.delfi.lt/news/daily/lithuania/ajokubaitislietuvos-respublika-nera-ldk-tesinys.d?id=58725361 (дата обращения 24.10.2020).

Сапожникова Г.М. Кто кого предал. Как убивали Советский союз и что стало с теми, кто пытался его спасти. М.: ИД Комсомольская правда, 2016. 352 с. 
Шепетис Н. Отсутствующая «национальная история» Литвы // Национальные истории на постсоветском пространстве - II / под ред. Ф. Бомсдорфа, Г. Бордюгова. М.: Фонд Фридриха Науманна, АИРО-ХХІ, 2009. 372 с.

Eidintas Alfonsas, Bumblauskas Alfredas, Kulakauskas Antanas, Tamosaitis Mindaugas. The history of Lithuania. Vilnius: Eugrimas, 2013. P. 70-74.

Kiaupa Zigmantas The history of Lithuania. Vilnius: baltos lankos, 2002. P. 109-123.

Kuolelis J. Gyvenimas post factum: pasikalbejjimas su draugu. Vilnius: Politika, 2017. 64 p.

Kuolelis J. Pro kalejjimo grotas: dviejų šimtmečių sandūros byla. Vilnius: Politika, 2010. 375 p.

Zinkevičius Z. Rytų Lietuva praeityje ir dabar. Vilnius: Mokslo ir enciklopedijų leidykla, 1993. 318 p.

Zverev, Kirill A.

\section{Collective Identity and Social and Political Behavior of the Population of Lithuania in Relationship with Historical State Policy}

\section{DOI: $10.33876 / 2311-0546 / 2021-3 / 42-52$}

The article examines the formation of the collective identity of the population of independent Lithuania during the 1990s - 2010s. in conjunction with local memory politics. At the time of gaining independence, in 1991, Lithuania was a multinational state, where, along with the Lithuanians, who constituted up to 79\% of the population, also lived Russian-speaking residents and Poles. As a result, the local authorities faced the need to construct not only their own political mechanism, the vertical of power, but also a collective national identity capable of becoming a fastening link of the emerging statehood. A significant role in achieving this goal was played by the Lithuanian historical policy, aimed not only at representatives of the titular population, but also at local national minorities. In this article, we attempt to trace the formation of collective identity, the socio-political behavior of Lithuanians, Russian-speakers and Poles through the historical views of these groups, as well as the degree of susceptibility of the population of the Republic to the state historical paradigm.

Keywords: state historical policy, politics of memory, Lithuania, Russian-speaking population

For Citation: Zverev, Kirill A. 2021. Collective Identity and Social and Political Behavior of the Population of Lithuania in Relationship with Historical State Policy. Herald of Anthropology (Vestnik Antropologii) 3: 42-52.

Author Info: Zverev, Kirill A. - PhD in Hist, Kostroma State University (Kostroma, Russia). E-mail: zwerew.kir@yandex.ru

\section{References}

Davidonite, B. 2016 [Research: how is life in Lithuania assessed in Soviet times?]. ru.DELFI. https://ru.delfi.lt/news/live/issledovanie-kak-v-litve-ocenivayut-zhizn-v-sovetskie-vremena.d?id=72137384 (accessed: 20.10 .2020 ).

Diukov, A.R. 2013. Protektorat "Litva". Tainoe sotrudnichestvo s natsistami i nerealizovannyi stsenarii utraty litovskoi nezavisimosti, 1939 - 1940 gg. [Protectorate "Lithuania". Secret collaboration with the Nazis and the unrealized scenario of the loss of Lithuanian independence, 1939-1940]. Moscow: Fond "Istoricheskaia pamiat"

Eidintas, A., A.Bumblauskas, A. Kulakauskas, and M. Tamosaitis. 2013. The history of Lithuania. Vilnius: Eugrimas, 70-74.

Garapko, V.F. 2016. Mirovozzrencheskie paradigmy i ideologemy vneshnei politiki sovremennoi 
Litvy [Worldview paradigms and ideologemes of the foreign policy of modern Lithuania]. International scientific review3 (13): 69-74.

Ivanov, V.V. 2018. De jure i de facto: istoriia formirovaniia etnopoliticheskogo gosudarstva litovtsev $v$ mezhvoennyi period 1919-1941 gg. [De jure and de facto: the history of the formation of the ethnopolitical state of the Lithuanians in the interwar period 1919-1941 in 4 volumes]. Vilnius.

Ivanov, V.V. 2006.Gekatomba. Trilogiia. Chast' 2. Strashnaia noch'. K voprosu o zhertvakh nochi 13 ianvaria 1991 g. $v$ Vil'niuse [Hecatomb. Trilogy. Part 2. A terrible night. On the issue of the victims of the night of January 13, 1991 in Vilnius. Collection of documents]. Sbornik dokumentov. Vilnius. https://www.proza.ru/2010/01/06/1087 (accessed: 08.12.2019).

Juozaitis, A. 2020. Vasario 16-oji buvo esminio lūžio taškas Lietuvos istorijoje [February 16 was a turning point in the history of Lithuania]. Lietuvos rytas [Lithuanian morning] https://kultura.lrytas.lt/-13288031681327725490-a-juozaitis-vasario-16-oji-buvo-esminio1\%C5\%AB\%C5\%BEio-ta\%C5\%A1kas-lietuvos-istorijoje.htm (accessed: 24.10.2020).

Kiaupa, Z. 2002. The history of Lithuania. Vilnius: baltos lankos.

Kuolelis, J. 2017. Gyvenimas post factum: pasikalbejjimas su draugu [Life post factum: talking to a friend]. Vilnius: Politika.

Kuolelis, J. 2010. Pro kalejimo grotas: dvieju šimtmečiu sandūros byla [Through the prison bars: the case of the junction of two centuries]. Vilnius: Politika.

Petkiavichius, V. 2004. Korabl' durakov: Galereia politicheskikh portretov i sharzhei [Ship of Fools: Gallery of political portraits and cartoons]; Translation from Lithuanian by V. Meshcheriakova, N. Koviakovoi. Kaliningrad: Iantarnyi skazp.

Samoshkaite, E., and A. Jokubaitis. 2020. Litovskaia Respublika ne iavliaetsia prodolzheniem Velikogo kniazhestva Litovskogo [The Republic of Lithuania is not a continuation of the Grand Duchy of Lithuania]. rus.DELFI.lv https://www.delfi.lt/news/daily/lithuania/ajokubaitis-lietuvos-respublika-nera-ldk-tesinys.d?id=58725361 (accessed: 24.10.2020).

Sapozhnikova, G.M. 2016. Kto kogo predal. Kak ubivali Sovetskii soiuz i chto stalo s temi, kto pytalsia ego spasti. [Who betrayed whom. How the Soviet Union was killed and what happened to those who tried to save it]. Moscow: ID Komsomol'skaia Pravda.

Shepetis, N. 2009. Otsutstvuiushchaia "natsional'naia istoriia" Litvy [Absent "national history" of Lithuania]. Natsional'nye istorii na postsovetskom prostranstve - II [National histories in the post-Soviet space - II], edited by F. Bomsdorfa, G. Bordiugova. Moscow: Fond Fridrikha Naumanna, AIRO-KhKhI.

Demurina M.V., Simindeia V.V. (eds.). 2009. Sovremennaia evropeiskaia etnokratiia: Narushenie prav natsional'nykh men'shinstv $v$ Estonii i Latvii [Contemporary European Ethnocracy: Violation of the Rights of National Minorities in Estonia and Latvia]. Moscow: Fond "Istoricheskaia pamiat".

Vorobieva, L. (ed.). 2010. Istoriia Latvii ot Rossiiskoi imperii $k$ SSSR. [History of Latvia from the Russian Empire to the USSR]. Book 2. Moscow: Fond "Istoricheskaia pamiat".

Zinkevičius, Z. 1993. Rytu Lietuva praeityje ir dabar [Eastern Lithuania in the past and now]. Vilnius: Mokslo ir enciklopedijų leidykla.

Zverev, K.A. 2020. Formirovanie ofitsial'noi istoricheskoi paradigmy nezavisimoi Litvy [Formation of the official historical paradigm of independent Lithuania]. Vseobshchaia istoriia 3: 03-13. 